\title{
Chapter 16 Irish Sea (including Kish Bank)
}

\author{
D. I. JACKSON, N. S. JONES \& C. N. WATERS
}

A thick and relatively complete succession of Carboniferous rocks of Tournaisian to Westphalian age, together with a probable Stephanian section (Floodpage et al. 2001) was deposited throughout the two main areas in the Irish Sea region. The larger Central Province Trough in the south includes the East Irish Sea Basin (EISB)-Quadrant 109 Syncline-Kish Bank Basin, linking the onshore successions of the Craven Basin (Chapter 11) and Dublin Basin (Chapter 21). The smaller Peel Basin-Solway Basin (Figure 16.1) represents the extension of the onshore Solway Basin (Chapter 13) and continues westwards between the Drogheda Shelf and the Balbriggan Block (Chadwick et al. 2001; Sevastopulo \& Wyse Jackson 2001). Seismic data suggest that there is probably some $4000 \mathrm{~m}$ to $5000 \mathrm{~m}$ thickness of Carboniferous strata in the Solway Basin and EISB (Chadwick et al. 2001). The present day distribution of Carboniferous strata is controlled by the effects of uplift and erosion associated with Variscan basin inversion (Chadwick et al. 2001). Separating the Solway Basin and EISB is the Manx-Lakeland Ridge, which is believed to extend westward to form the Balbriggan Block (Chapter 18).

The lithostratigraphical nomenclature of Jackson \& Johnson (1996) is retained. In this scheme the Tournaisian and Visean successions are referred to as the Garwood Group, the Namurian succession as the Bisat Group and Westphalian to Stephanian succession as the Kidston Group. There is insufficient information to subdivide these groups into component formations (Jackson \& Johnson, 1996). This primarily chronostratigraphical classification, which incorporates E-W to NE-SW facies belts (Figure 16.1; Cope et al. 1992; Jackson et al., 1995; Chadwick et al. 2001; Naylor 2001; Reay 2004), is at variance from the subdivision of onshore successions (Waters et al., 2007).

Offshore drilling into Carboniferous rocks within this region is sparse and unevenly spread. In the EISB 24 released wells have penetrated limited Carboniferous thicknesses beneath a Permo-Triassic cover (Jackson et al., 1995; Jackson \& Johnson, 1996; Chadwick et al. 2001). Several wells are known from other areas such as the Kish Bank Basin (Jenner 1981; Naylor et al. 1993; Dunford et al. 2001) and the Solway and Peel basins (Newman 1999; Chadwick et al. 2001; Floodpage et al. 2001). Numerous shallow BGS boreholes also occur in the Irish Sea (Wright et al. 1971; BGS 1994; Jackson et al., 1995).

Biostratigraphical control is very poor throughout the region, especially for Namurian to Stephanian strata. There are no released biostratigraphical reports for many of the drilled Carboniferous sequences. In early offshore wells in thick, sparsely fossiliferous distal facies (Jackson et al., 1995; Jackson \& Johnson 1996), too much reliance was placed on stage boundaries positioned using onshore zonations erected in proximal facies (cf. McLean et al. 2005; Riley et al. 1987). This account places greater weight on wireline log correlations and regional comparisons with well dated onshore sections. 


\section{Tournaisian}

The Langness Conglomerate Formation rests with angular unconformity on underlying Lower Palaeozoic strata in the southern part of the Isle of Man (Fig. 16.2, Col. 6) and comprises terrestrial, alluvial fan conglomerate, breccia and sandstone composed mainly of locally derived material (Dickson et al. 1987). The uppermost $10 \mathrm{~m}$ of the formation is finer grained, greyer and shows evidence for marine reworking (Chadwick et al. 1995). Little information is available on the nature of deposition during the Tournaisian and Visean on the partly concealed offshore Manx-Lakeland Ridge (Figure 16.1) and the offshore extent of alluvial and platform carbonate deposits evident onshore in west Cumbria (Chapter 12) is not known.

In the Central Province Trough, the undrilled Tournaisian rocks of the lower part of the Garwood Group of Jackson \& Johnson (1996) are believed to consist of exceptionally thick mud mound carbonates equivalent to the onshore Clitheroe Limestone Formation in basinal areas (Fig. 16.2, Col. 8) and of thinner terrestrial red beds equivalent to the onshore Marsett Formation (Fig. 16.2, Col. 8) towards the basin margins (Kirby et al. 2000; Chadwick et al. 2001).

The lower part of the Garwood Group in the Peel and Solway basins (Fig. 16.2, Cols. 2 \& 3 , respectively) includes mostly sabkha evaporite and peritidal carbonate rocks, with a lower succession of volcanic rocks thought to exist in the Peel Basin (Chadwick et al. 1995; Ward 1997; Chadwick et al. 2001; Mitchell 2004), although offshore information for these basins is very limited.

\section{Visean}

At the southern end of the Isle of Man (Fig. 16.2, Col. 6), early Visean rocks of the Great Scar Limestone Group comprise the Derbyhaven, Knockrushen and Balladoole formations. They predominantly comprise carbonate facies and record a marine transgression followed by gradual deepening from carbonate ramp to deep marine hemipelagic carbonate rocks. No strata of Chadian age have been recognised, the Derbyhaven Formation being interpreted as entirely of Arundian age, indicated by presence of the foraminifers Glomodiscus and Uralodiscus in the Sandwick Member ${ }^{\mathrm{O} 1}$ and the coral Michelinia megastoma in the overlying Skillimore Member $*^{2}$ (Chadwick et al. 1995). The Knockrushen Formation contains Archaediscus and Paleotextulariid foraminifers ${ }^{\mathrm{O} 3}$, suggestive of a Holkerian age (Chadwick et al. 1995). The Balladoole Formation lies slightly to the north and interfingers with late Visean hemipelagic facies at its southern edge. Ammonoids from bioherms within the Balladoole Formation are indicative of $a B_{2 a}$ and $B_{2 b}$ subzones ${ }^{+4}$ (Chadwick et al. 1995). The Manx-Lakeland Ridge (Fig. 16.2, Col. 5) during the Arundian to early Holkerian was probably associated with comparable shallow-marine carbonate ramp deposition.

The Lower Visean strata of the Peel Basin includes mud-mound carbonate rocks overlain by Arundian conglomerate, indicating a phase of renewed rifting or lowstand conditions (Chadwick et al. 2001). In the western edge of the Peel Basin Borehole 73/65 (Fig. 16.2, Col. $2^{\mathrm{O1}}$ ) proves bioclastic limestone with late Arundian foraminifers (Jackson et al. 1995). Within the Solway Basin coarse alluvial fan clastic and marine carbonates facies, 
are present on the northern margin of the basin (Deegan 1973). Little is known of the Lower Visean strata in the offshore Solway Basin, but the evaporite succession described from the onshore by Ward (1997) has a distinctive seismic character that can be traced within the Solway Basin and may link up with similar facies described from Northern Ireland (Smith 1986).

During the late Holkerian, highstand conditions resulted in drowning of many of the shallow water carbonate successions and deposition of hemipelagic carbonate rocks from the southern end of the Isle of Man and EISB (Figure 16.2, Cols. 6 \& 8, respectively). On the southern part of the Isle of Man (Fig. 16.2, Col. 6), the Craven Group comprises deep-marine hemipelagic carbonate rocks (Hodderense Limestone Formation) and deepwater black claystone with localised carbonate turbidites, debris flows and olistoliths (Bowland Shale Formation), and uniquely, volcaniclastic rocks and submarine basaltic lavas (the Scarlett Volcanic Member). Olistoliths recorded with ammonoids of $\mathrm{P}_{1 \mathrm{a}}$ Subzone ${ }^{+5}$ and from mudstones within the middle part of the formation contain the ammonoid Arnsbergites falcatus and bivalve Posidonia becheri of $\mathrm{P}_{2 \mathrm{a}}$ Subzone age ${ }^{+\sim 6}$ (Chadwick et al. 1995). Chadwick et al. (1995) inferred that the Solway Basin area was also an area of deeper water at this time. Late Visean deposition of thick marine shales and calciturbidites are recorded in the Peel Basin (Well 112/15-1) (Chadwick et al. 2001).

Platform carbonate rocks on the bounding shelves, such as the North Wales Shelf (Chapter 8) and the northern part of the EISB (Chapter 12) continued into the late Visean. Within the Central Province Trough there was a progressive deepening throughout the late Visean, interrupted by short hiatuses (Kirby et al. 2000; Johnson et al. 2001), with progressive encroachment of the largely carbonate succession upon the adjacent Lower Palaeozoic massifs. Platform carbonate deposition in the Peel Basin is proved in Well 111/29-1, with $366 \mathrm{~m}$ of grainstone and wackestone carbonate ramp deposits of Holkerian to Asbian age (Chadwick et al. 2001). A Brigantian carbonate succession equivalent to the Eskett Limestone Formation of north and west Cumbria (Chapter 12) has been recognised in Wells 112/25a-1 and 113/27-2 (Chadwick et al. 2001) located in the Lagman and Keys basins.

At the northern end of the Isle of Man (Fig. 16.2, Col. 4), upper Visean rocks are known only from boreholes and include platform carbonate rocks (Balladoole Formation), overlain by a mixed carbonate-clastic succession (Chadwick et al. 1995). This latter Yoredale facies extends at least into the early Namurian and has been proved offshore in Well 25/1. In the Solway Basin (Fig. 16.2, Col. 3), the Brigantian to Lower Pendleian upper part of the Garwood Group also includes mostly facies equivalent of the onshore Yoredale Group (Chadwick et al. 1995; Ward 1997; Chadwick et al. 2001; Mitchell 2004). Here, the transgressive limestone component of the cycles is very thin or absent.

\section{Namurian}

In the Peel and Solway basins the preserved Bisat Group (Jackson \& Johnson, 1996) has a limited present-day distribution (Fig. 16.2, Cols. 2 \& 3), which in the Solway Basin comprises thinly interbedded mudstone and sandstone of lower delta plain origin and 
equivalent to the Stainmore Formation of onshore northern England (Chapter 13). Namurian and younger sediments have been largely removed from the Peel Basin by prePermian and post-Jurassic erosion (Newman 1999; Floodpage et al. 2001). Most information is available for the comparatively thick successions of the EISB.

Strata of likely Pendleian age occur in boreholes on the northern tip of the Isle of Man with a c.70 m interbedded succession of mudstone, thin limestone, coal and sandstone immediately overlying the Great Limestone (Taylor et al. 1971). In the Shellag Point Borehole (also known as RTZ 1 or Shellag South) [SC 456 996] c. 27 m of mudstone are present, including two of the three Nuculoceras nuculum $\left(\mathrm{E}_{2 \mathrm{c}} 2-4\right)$ marine bands (Fig. 16.2, Col. $4^{+1}$ ), of latest Arnsbergian age (Riley et al. 1987).

In the centre of the EISB, during the Pendleian to Arnsbergian, , the Bisat Group contains relatively deep-water limestone and siltstone turbidites, and hemipelagic shales. Limited evidence suggests derivation of limestone turbidites from southerly quadrants (Ramsbottom 1969b; Davies et al. 2004) in the south of the area (adjacent to north Wales, Chapter 8), in contrast to the northern part of the area where distal siltstone and silty sandstone turbidites occur downslope of the northerly sourced Pendleian to Arnsbergian clastic turbidites (Jackson \& Johnson, 1996). In the northern EISB, the relatively thin Pendleian-Kindercoutian $\left(\mathrm{R}_{1 \mathrm{c}}\right)$ interval of monotonous silty mudstone may represent a delta slope by-pass area.

The Chokierian and Alportian 'hot shale' constitutes a very high gamma marker unit (cf. Kirby et al. 2000) in the central EISB (Fig. 16.2, Col. $8 \wedge^{1}$ ) of hemipelagic shales that has been dated to the upper SO miospore zone (composite logs; q.v. Jackson \& Johnson, 1996). The interval represents highstand condensed deposition that correlates with the newly defined Samlesbury Formation (Waters et al. in press; see Chapter 11). Significantly, this characteristic wireline log motif has not been recognized in wells in the northern EISB, though previous interpretations, based on palynological dating, have depicted a well developed (160 m thick) Chokierian-Alportian section (Jackson et al. 1995; Jackson \& Johnson 1996, p.149; Chadwick et al. 2001). Wireline log correlations suggest that the $\mathrm{H}$ biozone boundaries assigned from spore determinations in early commercial offshore wells are suspect (q.v. Riley et al. 1987; McLean et al. 2005). Comparisons with the distribution of Chokierian-Alportian strata in coastal NW England (see Chapter 12) corroborate the idea that their offshore correlatives in the northern EISB (Fig. 16.2, Col. 7) are either absent or very thin (5-10 m). A manifestation of the midNamurian hiatus between $\mathrm{G}_{1 \mathrm{~b}}$ and $\mathrm{E}_{2}$ strata seen in west Cumbria (Akhurst et al. 1997; Ramsbottom et al. 1978) is also likely to be present on the sediment-starved delta slope successions, south of the Manx-Lakeland Ridge. Chokierian and Alportian strata are also likely to be very thin or absent from the undrilled offshore Manx-Lakeland Ridge and over much of the Peel and Solway basins, though thin marine bands may occur (Chadwick et al. 2001, p.64).

During the late Kinderscoutian $\left(\mathrm{R}_{1 \mathrm{c}}\right)$ to Yeadonian interval fluvio-deltaic cycles of the Bisat Group, similar to, but more argillaceous than, the Millstone Grit cycles of the Pennines (Chapter 11), were deposited across the entire EISB. In the central EISB (Fig. 
16.2, Col. 8), the Kinderscoutian Substage in the Bisat Group (equivalent to the onshore Hebden Formation of Waters et al. in press) comprises a basal high gamma marine shale, sharply overlain by a widely distributed turbidite sandstone which is equated with the onshore Parsonage Sandstone (Price et al. 1963; Earp et al. 1961). This is succeeded by a thick succession of delta-slope silty mudstone, and then by siltstone capped by an argillaceous sandstone that represents the equivalent of the Upper Kinderscout Grit (Earp et al. 1961; Kirby et al. 2000). In contrast, in the northern EISB (Fig. 16.2, Col. 7; Jackson \& Johnson, 1996), Kinderscoutian strata consist of delta-slope silty mudstone, with numerous hemipelagic shale partings and two thin clean delta-top sandstone units. Kinderscoutian strata have not yet been drilled in the Peel and Solway basins and approximate thicknesses are assigned from isopach maps and regional comparisons with penetrations in adjacent onshore areas.

The offshore Marsdenian succession of the EISB, equivalent to the Marsden Formation of Waters et al. (in press), becomes finer grained and considerably thinner northwards; concomitantly, the sandstones become thinner and more argillaceous. Limited evidence suggests that the basin-shelf boundary was still controlling differential subsidence within the northern East Irish Sea Basin, with marked thinning to the north of this line. Further northward, thinning of the Marsdenian succession to $c .10 \mathrm{~m}$ probably takes place towards the crest of the undrilled Manx-Lakeland Ridge (cf. Akhurst et al. 1997; Ramsbottom et al. 1978; Ramsbottom 1978).

Throughout the offshore EISB, the Yeadonian succession, equivalent to the Rossendale Formation of Waters et al. (in press), thins steadily northwards (Fig. 16.2, Cols. 7 \& 8), suggesting that the northern shelf-to-basin break in slope had finally been eliminated. The thickness changes relate to regional subsidence with a depocentre in the far south of the basin, as evident onshore (see Chapter 11). The succession continues to thin northwards onto the undrilled offshore Manx-Lakeland Ridge (Akhurst et al. 1997; Ramsbottom et al. 1978). Yeadonian strata from the Isle of Man Borehole 2 (Shellag North) [SC 462 007] (Fig. 16.2, Col. 4) preserves a thin shallow water deltaic succession including upwards-coarsening mouth bars, marine bands, palaeosols and channel facies (Chadwick et al. 1995).

\section{Westphalian}

The Westphalian succession of the UK sector of the Irish Sea region is referred to the Kidston Group (Jackson \& Johnson 1996). This comprises a typical Pennine Basin succession of grey fluvio-lacustrine ('Coal Measures') facies of Langsettian to midBolsovian age equivalent to the Pennine Coal Measures Group of onshore areas, overlain by a primary red-bed alluvial facies of late Bolsovian to Asturian age, equivalent to the onshore Warwickshire Group (cf. Waters et al. in press; Waters \& Davies 2006; see Chapters 8, 11 and 12). The distinction between the EISB and Solway - Peel basins became less marked during deposition of the Kidston Group (Jackson \& Johnson 1996). Only Westphalian rocks were present in the sole well to penetrate the Carboniferous in the Kish Bank Basin (Fig. 16.2, Col. 1; Jenner 1981; Naylor et al. 1993; Dunford et al. 2001). 
In the offshore western part of the Pennine Basin, Westphalian strata are preserved as outliers, chiefly in synclinal cores or the hangingwalls of half graben, both at outcrop and subcropping Permo-Triassic rocks (Fig 16.1). In the EISB, Westphalian rocks are now confined to a northern tract including the exceptionally thick preservation (c.4000 m) in the Quadrant 109 Syncline (Fig. 16.2, Col. 7), and to a southern tract offshore from the Lancashire and Flintshire coalfields (Fig. 16.2, Col. 8; Williams \& Eaton 1993; BGS 1994; Jackson et al. 1995; Jackson \& Johnson 1996; Chadwick et al. 2001). Elsewhere, Westphalian deposits straddle the Manx-Lakeland Ridge, particularly in the offshore extension of the West Cumbria Coalfield (Fig. 16.2, Col. 5; Taylor 1961; cf. Akhurst et al. 1997; Chadwick et al. 2001), and they core the Solway Syncline (Fig. 16.2, Col. 3; Chadwick et al. 1995, map 14).

Substage biostratigraphical determinations in shallow offshore BGS boreholes are summarised in Jackson et al. (1995). The Kish Bank Basin succession has provided the most precise miospore dates (Jenner 1981; Naylor et al. 1993). Elsewhere offshore, biostratigraphical data for the Kidston Group are sparse, generally of very poor quality and on occasions contradictory and this compilation has relied upon wireline log correlation, characterized by moderate to highly serrate, linear profiles, to determine substage boundaries and thicknesses. Formal subdivision of the Kidston Group has not been attempted here, but facies and lateral correlatives of formations belonging to the onshore Pennine Coal Measures and Warwickshire groups can be recognized over wide areas (Fig. 16.2).

Langesttian strata, including the Subcrenatum Marine Band, are known from the Ballavaarkish Borehole (also known as Shellag North) [SC 462 007] at the northern end of Isle of Man (Fig. 16.2, Col. 4) (Chadwick et al. 1995). The marine band contains the inarticulate brachiopod Lingula mytilloides and the ammonoid Gastrioceras subcrenatum ${ }^{+2}$. The lowermost part of the Langsettian comprises claystone and siltstone.

In the EISB (Fig. 16.2, Cols. 7 \& 8), the Subcrenatum Marine Band has been positioned at a modest gamma-ray spike (Whittaker et al. 1985) sandwiched between two sheet sandstones, believed to be the lateral equivalents of the Woodhead Hill Rock and Rough Rock (Chapter 11). Lower Langsettian strata were not deposited on the more elevated flanks of the Lower Palaeozoic massifs, e.g. the Kish Bank Basin (Fig. 16.2, Col. 1; Jenner 1981; Naylor et al. 1993).

In the southern EISB (Fig. 16.2, Col. 8), wireline logs allow informal divisions and individual coals of early Langsettian age to be closely correlated with the thicker succession in the Lancashire Coalfield depocentre (Aitkenhead et al. 2002). The interval between the equivalents of the Pasture Mine and Arley Mine comprises an especially prominent $80 \mathrm{~m}$ thick mudstone succession lacking coals (cf. Chisholm 1990). Wireline log correlations demonstrate considerable northward thinning into the northern EISB (Fig. 16.2, Col. 7), where measures of early Langsettian age contain a persistent $100 \mathrm{~m}$ thick mudstone between the local equivalents of the Woodhead Hill Rock and Old Lawrence Rock. 
Langsettian to Bolsovian measures have been proved in offshore coal boreholes and worked offshore on the northern flanks of the Manx-Lakeland Ridge (Fig 16.1; Fig. 16.2, Col. 5; Taylor 1961), and identified on seismic data in the innermost Solway Basin (Fig. 16.2, Col. 3; Chadwick et al. 1995; cf. Picken 1988).

The best documented Duckmantian section is found in the Kish Bank Basin (Fig. 16.2, Col. $1^{\wedge 1}$ ), where measures containing the miospores Dictyotriletes mediareticulatus and Raistrickia fulva comprise interbedded siltstone and sandstone with minor coal seams above a basal $10 \mathrm{~m}$ thick transgressive sandstone unconformably overlying Tournaisian to Namurian strata (Naylor et al. 1993). A complete Bolsovian section in the Kish Bank Basin (Fig. 16.2, Col. $1^{\wedge}$ ), has yielded the miospores Vestispora costata and $V$. pseudoreticulata from a grey typical fluvio-lacustrine ('Coal Measures') succession (Naylor et al. 1993).

The Symon Unconformity of intra-Bolsovian age and separating the Pennine Coal Measures Group from the Warwickshire Group is believed here to be present over large parts of the Irish Sea (Jackson \& Johnson 1996; cf. Smith et al. 2005). An unconformity at this level occurs beneath the Etruria Formation (equivalent) offshore from North Wales (Williams \& Eaton 1993; cf. Davies et al. 2004), is seen on seismic data at the base of the Warwickshire Group (equivalent) in the northern EISB (Chadwick et al. 2001), is found at the base of the Whitehaven Sandstone Formation on the Manx-Lakeland Ridge (Akhurst et al. 1997), is possibly developed in the Kish Bank Basin (Jenner 1981) and has its greatest expression around Anglesey (Jackson et al. 1995).

In the Kish Bank Basin, an incomplete Asturian succession of grey mudstone, siltstone and thin sandstone (Fig. 16.2, Col. $1^{\wedge 3}$ ), contains Vestispora magna some $127 \mathrm{~m}$ above the base of the substage (Naylor et al. 1993). The uppermost $114 \mathrm{~m}$ comprise varicoloured grey, red and brown measures that could either represent partially secondarily reddened strata below the now eroded Permo-Triassic cover, or might form part of the Warwickshire Group (Chapters 8-12).

Scant and poor quality drilling data from the northern EISB (Fig. 16.2, Col. 7) show presumed uppermost Bolsovian to lower Asturian equivalents of the lowermost Warwickshire Group. The succession comprises some $80 \mathrm{~m}$ of variegated off white to red-brown mudstone, overlain by $90 \mathrm{~m}$ thin, grey, silty sandstone, red-brown siltstone and mudstone, typically in upward-fining alluvial cycles, averaging $50 \mathrm{~m}$ in thickness. Equivalents of the Halesowen Formation and probably also the basal Salop Formation occur offshore to the north of the Flintshire Coalfield (Fig. 16.2, Col. 8; Williams \& Eaton 1993; Davies et al. 2004). In the offshore West Cumbria Coalfield the equivalent of the Whitehaven Sandstone Formation oversteps progressively southwards across Bolsovian and the uppermost Duckmantian measures towards the crest of the ManxLakeland Ridge (Fig. 16.2, Col. 5; cf. Akhurst et al. 1997; q.v. Taylor 1961, Plates I and II), and a thick Asturian age sequence occupies the innermost Solway Basin (Fig. 16.2, Col. 3; cf. Picken 1988, Chadwick et al. 1995, map 14). A full but untested Asturian succession is present in the Quadrant 109 Syncline (Fig. 16.1; Fig. 16.2, Col. 7; Jackson \& Johnson 1996). 


\section{Stephanian}

A thick succession of Stephanian age was probably deposited over most of the Irish Sea area (Jackson \& Johnson, 1996; Floodpage et al. 2001) but has mostly been removed by pre-Permian and post-Jurassic erosion. Erosional remnants of this succession, equivalent to the onshore Warwickshire Group (Salop and possibly younger formations), are probably now confined to the Kish Bank Basin (Fig. 16.2, Col. 1; Jenner 1981; Dunford et al. 2001; Floodpage et al. 2001), to the Solway Syncline (Fig. 16.2, Col. 3; Chadwick et al. 2001), the undrilled core of the Quadrant 109 Syncline where the Stephanian succession is conjectured to reach over $1500 \mathrm{~m}$ in thickness (cf. BGS 1994; Jackson et al. 1995; Jackson \& Johnson 1996; Floodpage et al. 2001) and to small outliers scattered elsewhere in the EISB (Fig. 16.1).

Figure 16.1. Distribution of Carboniferous rocks in the Irish Sea area and general location of Columns 1-16 modified and updated from BGS (1994), Jackson et al. (1995), Jackson \& Johnson (1996), Chadwick et al. (2001).

Figure 16.2. Correlation chart of Carboniferous rocks in the Irish Sea region. Columns 1 - 8 are arranged from west to east in a northward swinging semi-circle (see figure 16.1 for locations). It should be noted that all substage thicknesses for the Pennsylvanian strata of offshore areas on Figure 16.2, both from drilled successions and inferred from adjacent onshore areas, are less secure than in onshore areas, since the particular marine band has not been identified. 


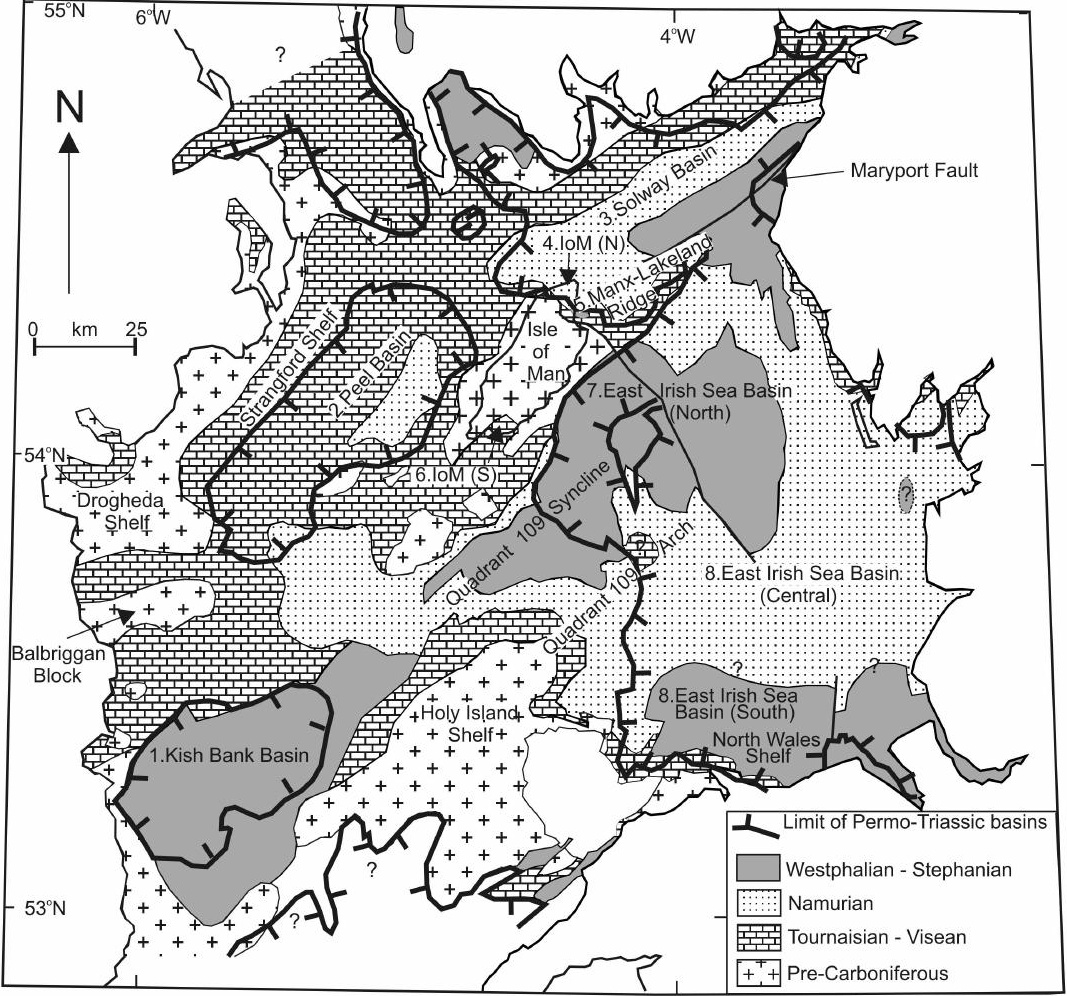


